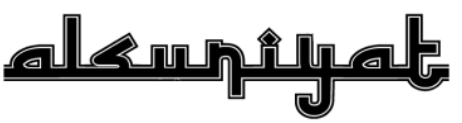

JURNAL PENELITIAN BAHASA, SASTRA, DAN

BUDAYA ARAB

P-ISSN: 2615-7241 | E-ISSN: 2721-480X // Vol. 3 No. 2 | 101-110

† https://ejournal.upi.edu/index.php/alsuniyat/index

\title{
Teaching Arabic-English Translation in the University of Ilorin Nigeria: Any Challenges?
}

\author{
Aliy Abdulwahid Adebisi, Abdur-Rasheed Mahmoud Mukadam \\ University of Ilorin, Nigeria \\ Email: adebisi.aa@unilorin.edu.ng
}

\begin{abstract}
:
The practice of translation generally presents a lot of difficulties and issues. The process becomes more complicated when dealing with teaching translation especially in higher institutions. This study examines the dynamics of teaching the practice of translation taking the example of University of Ilorin. Thus, the study investigates the significance of translation teaching, teaching materials, techniques and teaching methods. This is done with a view to uncovering the challenges encountered by concerned lecturers teaching translation courses at the University of Ilorin. In this study, a descriptive approach was utilized in identifying the problems associated with teaching translation. With this method, questionnaires (containing 11 questions open ended) were administered. This research reveals the challenges encountered and proposes some practical procedures to resolve them. The outcomes and recommendations also proffer new vistas and possible solutions which would assist facilitators and other stakeholders to improve the way translation is taught in the University.
\end{abstract}

\section{Keywords:}

Teaching Arabic-English; Translation; Challenges

\section{INTRODUCTION}

Translation as the reproduction of the meanings of the contents of a text from one language into another, plays vital roles in multilingual societies (Abubakre \& Abdussalam, 2019, p.194). The important roles of translation in human communication universally from time immemorial until now.

Furthermore, teaching translation is a professional task, hence a translation teacher must be a professional in the field. According to Al Mubarak Amin Ali (2017) translation teachers must have dual expertise of, being proficient in teaching the principles of translation in one part and simultaneously having the practical skills of an actual translator. However, many researchers have studied the prospects and difficulties in the teaching of translation.

Critchley et. al. (1996) as quoted by Al Aqad Mohammed H. (2017) says, some people believe that translation courses could be more directed to developing professional translation skills, while others believe that teaching translation courses is neither realistic nor relevant to the work of a professional translator. Gerding-Salas (2000) says that consequences of wrong translations can be disastrous-especially if done by non-professionals.

Menck (1991, p.108) says scholars on teaching translation seem to agree on two things: firstly that there is a difference between translation in foreign-language teaching and 
translation teaching for professional purposes and secondly that a functional approach to translation should be adopted. In reference to Rami Al-Hamdallah (1996) on practical examples of translation problems facing Arabic-speaking translator trainees at the college level; he noted that there are two approaches to translation (and many compromises between them): assuming that you start translating sentence by sentence in the first paragraph or chapter, to get the feel and the feeling tone of the text, and then you deliberately sit back, review the position and read the rest of the SL text; (2) Read the whole text two or three times and find the intention, register, tone, mark the difficult words and passages and start translating only when you have taken your bearings. On another pedestal, Gabris (2000) claims in his study that "a translation instructor must be familiar and versed in translation and be capable of teaching translation courses at the university level since familiarity and experience of both languages are crucial."

However, on some vital points to be considered during the teaching of Translation, Larsen-Freeman and Anderson (2013) point out that: When teaching a student who is learning another language simultaneously, it is necessary for the instructor to put into consideration two important issues; firstly, there is a discrepancy between learning how to survive with translation related challenges and learning the language itself, though a relationship exists between the duo. Secondly, it is important to determine what approach befits the translation technique employed as well as the process chosen for translation because translation according to Estelle $(2019, \mathrm{p} .84)$ is a major medium of transmission and dissemination of information and knowledge. It is therefore a profession that needs to be practiced by competent people.

In another word, the importance of translation studies cannot be underestimated Iloh (2019, p.161) Owing to the steady advancement in science, society and innovation in the modern days, the demand for translation skills is on the increase. Teaching in general is challenging and teaching translation specifically is highly more challenging in view of the fact that conveying thoughts and experiences to someone else necessitates a sound mastery of topics together with the authority of the correspondence of knowledge. Similarly in current days, teaching in the field of translation studies should reciprocate advancement in education in terms of content and methodology. This area of study is very sensitive as it requires a good level of precision in order to avoid distortion of communication that translation is ordinarily meant to enhance. 
Hence, mistakes in this field may be disastrous. The level of disaster is described here using an analogy of mistakes in chemical texts as capable of causing fatal poisoning or a terrible explosion; that of a faulty translation in legal field leading to the loss of a lawsuit and crashing a plane from the sky in aeronautics. This is buttressed by Al Aqad asserting that a poor performance of an interpreter can spoil the proceedings of a whole international conference. The poor performance of an interpreter can spoil the proceedings of a whole international conference (Al Aqad M.H.). It has been observed that in Nigeria, translation constitutes courses offered in foreign language departments of the universities. Experience has shown that translation teaching presents scores of problematic domains, this seems to be true as regards the teaching/learning of Arabic/English translation to Anglophone learners.

Based on classroom experience, conclusion has been drawn by Rita (2015) that students encounter linguistic problems in the course of translation. Central to the acquisition of translation skills, the translation students should be able to read and write not only in his first language but also to read across his languages of operation. In this study, the researchers aim to point out some challenges facing the teaching of Translation (Arabic-English-Arabic) at the University of Ilorin. However, attention has been drawn to the fact that many studies have been rendered on various aspects of the problems of teaching languages in Nigeria.

However, there is no study on the challenges facing teaching of translation at the University of Ilorin which is the major aim of the present paper. The present study is to examining if there is challenge in the teaching of Arabic-English Translation in the University of Ilorin.

\section{METHOD}

Sample of the study: since the aims of the study were to identify the challenges encountered during the teaching of translation in the university and to appraise some prospects, about $50 \%$ of the 18 lecturers in the department of Arabic were involved in the survey. Some major criteria were considered as rationale behind choosing this particular group of teachers as participants. Such criteria considered include; their specialization in translation which is a key criterion and their experience in the field is another one since they have been teaching such courses for many years though, 50\% of Arabic lecturers is not good enough to represent the whole university.

In the sampling of population or data for the research, the study used University of Ilorin as a case-study. The target population is essentially departments which offer translation 
courses within the University of Ilorin such as English, French, Arabic, Linguistics and Nigerian Languages among others. Concretely, the Department of Arabic is the only clustered sample used for this study. The Department of Arabic consists of 18 lecturers of which 12 lecturers were sampled. $75 \%$ of the sampled lecturers (9 out of 12) provided feedbacks on their opinions regarding this study.

The study design assisted in conducting the survey in a systematic manner. Data analysis involves some related procedures. Data processing entails data analysis, discussion and classification. However, to obtain statistical data, structured questionnaire was administered to the participants towards unveiling the challenges of taking translation courses at the University of Ilorin. The principle objective was to examine the challenge facing teachers in the field of translation pedagogy. The questionnaire items and format were defined and designed by the researcher. However, personal experience of the researcher in the field of translation also influenced the data collection.

The survey was premeditated to discover the obstacles related with conveying the teaching the non-theoretical properties of translation at the university. Consequently, a measureable method was used for the data collection focusing on the University of Ilorin. In this study, a total of nine respondents were involved as detailed earlier at the sample of the study section. Confidentiality of the respondents in terms of identities, responses to the questions and demography were ensured since they have no impacts on the level of analysis in this study. However, questionnaire was the only tool used by the researcher for data collection. The survey was put in place to identify the challenges faced by teachers in the field of translation studies as well as general environments for teaching translation.

\section{RESULTS AND DISCUSSION}

The frequency distribution of the participants responses to the eleven problems of teaching translation in the University of Ilorin indicates that almost all the participants strongly agree that teaching translation in the University of Ilorin still lack of proficiency on teaching translation and linguistic resources that may enhance the quality of the translation. More specifically, the study examined two dimensions related with teaching translation, namely, problems and prospects of teaching translation. These frequencies are listed in table 1 below based on three given criteria, namely, strongly agree, agree, and disagree. 
Table 1

Problems of Teaching Translation in University of Ilorin

\begin{tabular}{|c|c|c|c|}
\hline \multicolumn{4}{|c|}{ Frequency (percentage) $n=9$} \\
\hline $\begin{array}{l}\text { Problems of Teaching Translation in University of } \\
\text { Ilorin }\end{array}$ & $\begin{array}{l}\text { Strongly } \\
\text { Agree }\end{array}$ & Agree & Disagree \\
\hline $\begin{array}{l}\text { Deficiency of students in grammatical competence and } \\
\text { cultural knowledge of a target language is one of the } \\
\text { significant problems of teaching Translation. }\end{array}$ & $(85)$ & (5) & \\
\hline $\begin{array}{l}\text { Language laboratories and necessary equipment for } \\
\text { translation are lacking resulting in more theoretical } \\
\text { sessions than practical }\end{array}$ & $9(100)$ & & \\
\hline $\begin{array}{l}\text { The most prominent issue in teaching translation is the } \\
\text { absence of suitable textbooks modeling translated } \\
\text { samples of the Arabic language into English. }\end{array}$ & & & $9(100)$ \\
\hline $\begin{array}{l}\text { Negative attitude of learners towards translation } \\
\text { studies is a barrier for translation teachers to attain } \\
\text { their teaching aims in teaching translation }\end{array}$ & & & $9(100)$ \\
\hline \multicolumn{4}{|c|}{ Prospects of Teaching Translation in University of Ilorin } \\
\hline $\begin{array}{l}\text { Teachers of translation need trainings and seminars in } \\
\text { order to be updated from time to time on the } \\
\text { developments in translation studies. }\end{array}$ & $8(90)$ & $1(10)$ & \\
\hline $\begin{array}{l}\text { A functioning internship should be part of students' } \\
\text { translator training programmes }\end{array}$ & $8(90)$ & $1(10)$ & \\
\hline $\begin{array}{l}\text { Enough credit hours should be added to teaching } \\
\text { Translation }\end{array}$ & $8(90)$ & $1(10)$ & \\
\hline $\begin{array}{l}\text { The teacher of translation needs to be a member of at } \\
\text { least two (2) translation learned societies and } \\
\text { professional bodies }\end{array}$ & $(95)$ & (5) & \\
\hline $\begin{array}{l}\text { The teacher of translation requires a good level of } \\
\text { competence in both the source and target languages }\end{array}$ & $9(100)$ & & \\
\hline $\begin{array}{l}\text { Teacher must be highly educated in the theories of } \\
\text { translation, general linguistics, literature and } \\
\text { aesthetics. }\end{array}$ & $9(100)$ & & \\
\hline $\begin{array}{l}\text { Teachers must possess the knowledge of error analysis } \\
\text { to know the causes of errors that emerge from the } \\
\text { usages in the areas of linguistics, culture and literature }\end{array}$ & $8(90)$ & $1(10)$ & \\
\hline
\end{tabular}

Table 1 shows that the analysis is divided into two sections - Problems and Prospects of teaching translation. In the first section, on the one hand, the data show that most of the participants strongly agree with the problems that grammatical competence and the cultural knowledge of the target language are of the significant problems of teaching translation. On the contrary, it is indicated that the most vital problem is the lack of language laboratories and necessary equipments (e.g., linguistic labs), which is agreed by all participants. On the other 
hand, the participants disagree with the problem that says translation occurs due to the absence of textbooks and the students attitude to learn translation. In the second section, the data consists of seven prospects concerning with the teachers competence in the translation and teaching translation. The seven problems are rated strongly agree and agree by the participants. Figure 1 and 2 below show the percentage bar chart of the respondents' opinions.

\section{Figure 1}

Frequency of the Problems of Teaching Translation in University of Ilorin

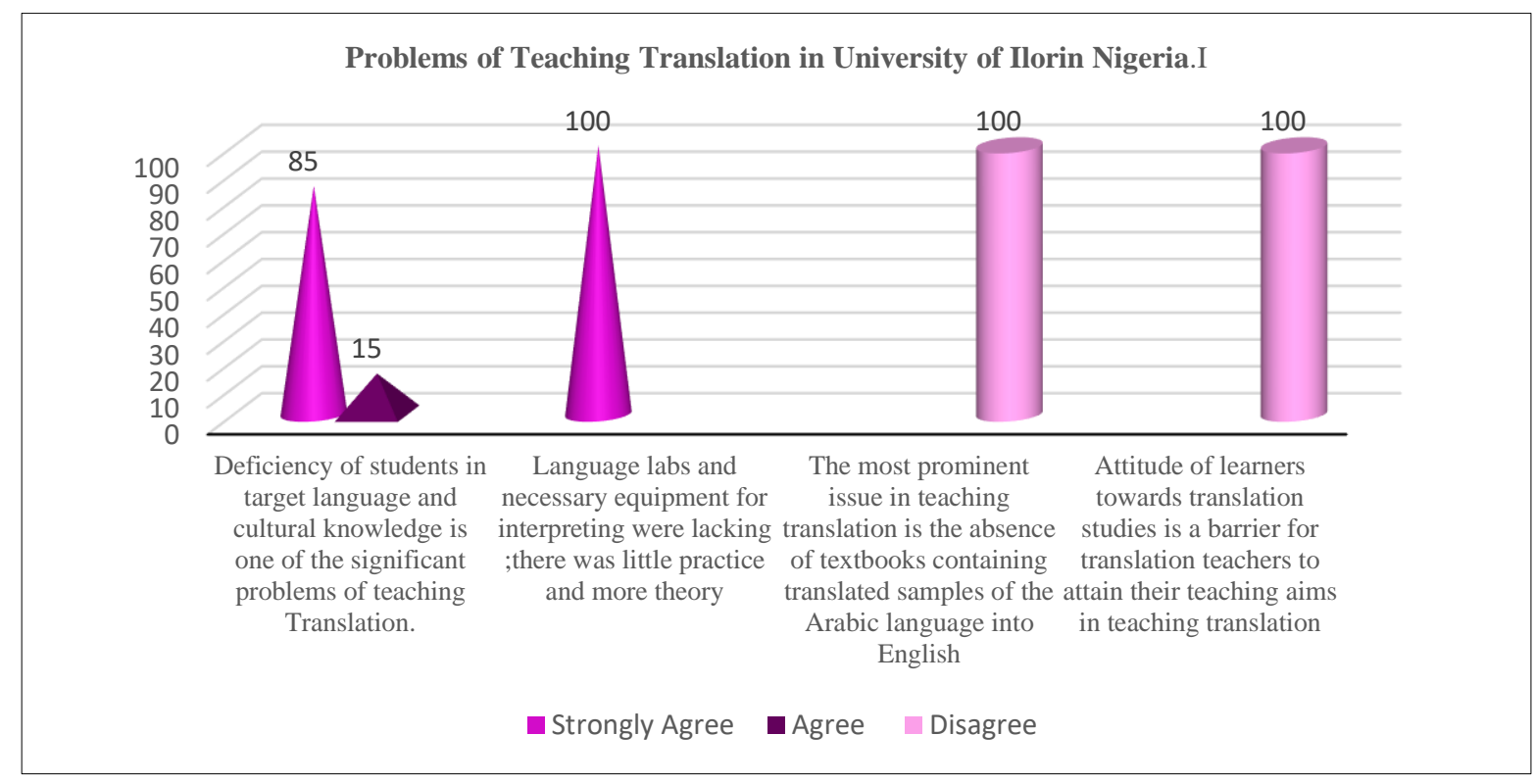

Figure 1 shows the frequency distribution of the four problems of translation in the University of Ilorin Nigeria. Of all the 11 questions, 4 questions are targeted at the problems facing teaching translation. One-hundred $100 \%$ of the respondents strongly believe that language laboratories and necessary equipment are unavailable for teaching translation therefore making it difficult to have practical sessions. Eighty-five 85\% agreed in strong terms and $15 \%$ simply agreed that students deficiency and cultural knowledge of the target language is indeed a barrier to teaching translation. Conversely, $100 \%$ of the respondents simply disagreed to the notion that unavailability of translated Arabic-English text and students attitude are among prominent issues in translation studies. These problems highlight the importance of creating a linguistic environment that may enhance the teaching of translation. Language laboratories and technology facilitate the teachers and the learners to access to a huge amount of knowledge concerning with translation in the sense that they can take benefit of the available online resources. In addition, delving through the cultural knowledge of the target language can be achieved only by involving the teaching staff to settle 
them in the country of the target language to interact with the native speakers. Therefore, acquiring the linguistic elements of the target language does not assist the translator to come up with a full understanding of the speaker unless he/she delve in the cultural knowledge of that language and most importantly interact with its speakers. Each text is related with its context, and each context cannot be understood fully without activating a huge amount of cultural knowledge and linguistic knowledge.

\section{Figure 2}

\section{Frequency of the Prospects of Teaching Translation in University of Ilorin}

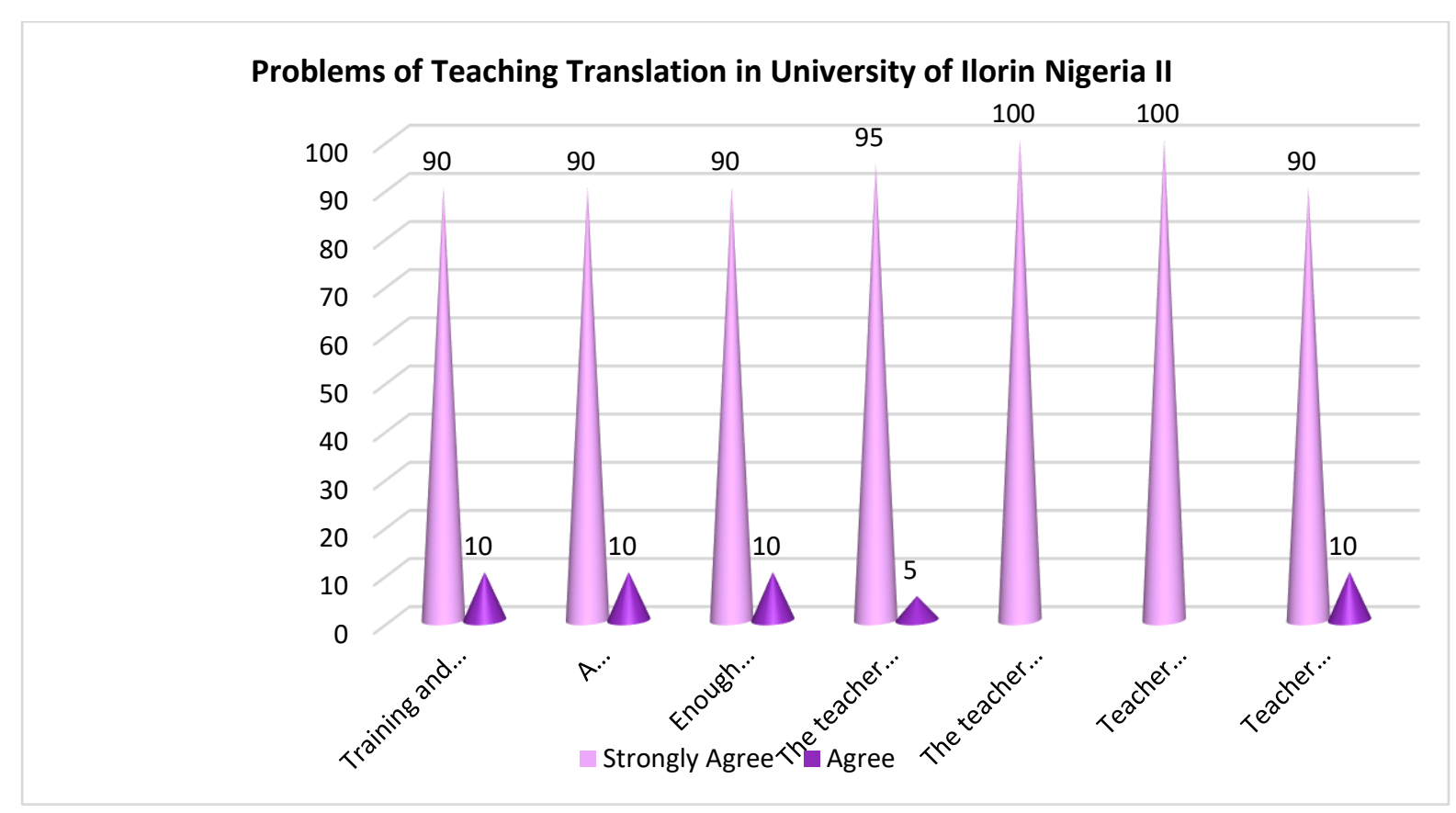

In Figure 2, the results show that all of the respondents agreed to all the 7 highlighted prospects of teaching translation. In strong terms, 100\% agreed that teachers must have linguistic knowledge of both source and targeted languages and as well as being highly refined in theories, linguistics, literature and aesthetics. Linguistic knowledge of the target language, which consists of all the linguistic sources from phonology to pragmatics, paves the way for translators to be translator-to-be and able to interpret the message. This linguistic knowledge contributes to produce efficient translation and professional translators. More so, $95 \%$ of the respondents strongly believed that translation teachers need to be a member of at least two translation professional bodies. Finally, $90 \%$ and $10 \%$ of the respondents strongly agreed and simply agreed respectively to other prospects in the questionnaire including organizing trainings and seminars from time to time for teachers, availability of internship for students, increasing the credit hours for translation courses and training teachers on error analysis in linguistics. Organizing such events and seminars may enhance the teachers to remain updated 
and fulfill the characteristics of translation competence, namely, complexity, heterogeneity, approximation, open-endedness, creativity, situationality and historicity. Bearing in mind the characteristics of translation, it is essential for the translator to develop the translation competence in three ways, namely, the acquisition of new knowledge, updating existing knowledge, and the strategic competence. In addition, it can be said that translators have not only develop linguistic factors, but also develop a huge amount of interdisciplinary factors such as epistemic memory, code-switching, ability to control interference, self-confidence in performance, communication skills, persistence in problem solving. There must be a constant training courses and seminars in translation studies that may enhance the pragmatic competence of the teachers to be equipped with updated knowledge and in their turn transfer to their students. On the other hand, the teachers of translation must create and educational conducive environment in their classes with open and free discussion and facilitate the learners with accurate feedback. The study exposes the possible problems that are associated with the procedures of teaching the theories and practice of translation, and these include lack of necessary training and seminar by the teachers, outdated teaching curriculum begging to be reviewed, inadequate training equipment and lack of translation and interpretation laboratory.

\section{CONCLUSION}

In conclusion, the following implications and recommendations are suggested in the light of the research findings: regular training and seminars are necessary for the betterment and development of translation teachers. The teacher of translation needs to be a member of at least two translation learned societies and professional bodies particularly NITI for Nigerian environment. Translation instruction after every theoretical guideline should allot more time to practicing by students both orally and in a written mode. Translation requires a special teaching methodology that is learner-centered, hence a translation teacher should be a trained teacher.

\section{REFERENCES}

Abubakre, S. 0 \& Abdussalam A. S. (2019). Analysis of strategies for translating culture specific expressions in Soyinka's in the forest of Olodumare in language. Pedagogy \& social discourse in honour of Prof. Tunde Ajiboye at 70(Ed) Isaiah. Ilorin: Department of French, University of Ilorin. 
ALSUNIYAT: Jurnal Penelitian Bahasa, Sastra, dan Budaya Arab

Al Aqad, Mohammaed. (2017). Challenges and suggested solutions of teaching translation at Gaza strip universities (Palestine). Arabic Language, Literature \& Culture, 2(2), 34-39. doi: 10.11648/j.allc.20170202.11

Barcsak. (1996). Teaching literary translation-a student's point of view. Teaching translation and interpreting. John Benjamins Publishing Company. https://doi.org/10.1075/btl.16.24bar

Bell. (1991). Translation and translating: Theory and practice. Taylor \& Francis.

Brain. (1990). On translation and translators. U.K: Oxford: Oxford University Press.

Delisle, Jean. (1984). Bridging the language solitudes: Growth and development of the Translation Bureau of the Government of Canada 1934-84. Ottawa: Secretary of State.

Estelle, M \& Servais, A. (2019). Translation and globalisation in language, pedagogy \& social discourse in honour of Prof. Tunde Ajiboye at 70(Ed) Isaiah, Ilorin: Department of French, University of Ilorin.

Frank, C. (2005). Teaching and learning theory: Who needs it?. College Quarterly, 8(2), 1-14.

Fry, Ketteridge \& Marshall. (2003). Understanding student learning, a handbook for teaching and learning in higher education: Enhancing academic practice. London: Kogan Page.

Gerding-Salas. (2000). Teaching translation. Translation Journal, 4(3), 50-62.

Gouadec. (2000). Notes on translator training (replies to a questionnaire). International Symposium on Innovation in Translator and Interpreter Training, 11-19.

Hatim \& Mason. (1990). Discourse and the translation. London and New York: Longman.

Iloh, N. (2019). French language and translation studies in Nigerian Universities in the $21^{\text {st }}$ century: Retrospection and prospection. Journal of West African Institute of Translators and Interpreters (JoWAITI), 161-181.

Kiraly, D. (1997). Collaborative learning in the translation practice classroom. Translations didaktik. Tübingen: Oxford University Press.

Kiraly, D. (2000). A social constructivist approach to translator education: Empowerment from theory to practice. Manchester: St. Jerome Publishing.

Klein-Braley, C. (1996). Teaching translation in universities: Present and future perspectives. London: AFLS.

Kussmaul, P. (1995). Training the translator. Amsterdam and Philadelphia: John Benjamins.

Larsen-Freeman \& Anderson. (2013). Techniques and principles in language teaching 3rd edition. Oxford: Oxford university press. 
Legutke, M., \& Thomas, H. (1991). Process and experience in the language classroom. London: Longman.

Li, Defeng. (2000). Making translation testing more teaching-oriented: A case study of translation testing in China. Meta: Journal des traducteurs Meta:/Translators' Journal, 51(1), 72-88. https://doi.org/10.7202/012994ar

Liu Jinyu. (2013). Translators training: Teaching programs, curricula, practices. Journal of Language Teaching and Research, 4(1), 127-132.

Mebitaghan, R. (2013). Error analysis and collaborative learning as learner-centered approaches to translation teaching: A Social Constructivist Approach. ANSU Journal of Arts and Social Sciences: A Journal of the Faculty of Arts and Social Sciences, Anambra State University, 2(1), 107-115.

Munby, John. (1978). Communicative syllabus design. Cambridge: Cambridge University Press.

Sanni-Suleiman, A. (2014). Religious issues and foreign language learning in Nigeria: The case of Arabic and French in Ilorin metropolis. Centrepoint Journal (Humanities Edition), 17(1).

The Department of Arabic. (2017). Students hand book University of Ilorin. Ilorin: Unilorin Press. 